\title{
RAZUMEVANJE IN POMEN KAZNOVANJA IN KAZNOVALNIH POLITIK NEKOČ IN DANES
}

\section{POVZETEK}

Kaznovanje ima dvojni pomen, na eni strani je nujno, ker privede do spoznanja zmotnega ravnanja, na drugi strani pa povzroči čustveno neravnovesje med učiteljem in gojencem. Teorije kaznovanja poznajo tri temeljne smeri - retributivistično, ki na posameznika deluje tako, da ne bo želel dejanja ponoviti; utilitaristično, katere temeljni cilj je sprememba posameznika, ter abolicionistično, ki se zavzema za alternativne oblike reševanja sporov in deviantnega vedenja. V današnjem času so vse bolj odmevni učinki ničte tolerance. To je politika reagiranja na deviantna vedenja, ki predvideva enake kazni za večje in manjšse prestopke. Njej nasprotni pol pa je inkluzija, katere cilji so oblikovanje ljudi različnih sposobnosti, mirno sožitje in razvijanje vrednot. Vzgojo si težko zamišljamo brez kaznovanja, čeprav uporaba kazni povzroči negativni učinek. Teoretično gledano, če je kazen vse, kar kaznovani doživlja kot neprïetno, potem kazni v vzgoji ni mogoče odpraviti. Klasične kazni pa je mogoče nadomestiti z ukrepi, ki jih predlagajo nasprotniki klasičnega kaznovanja.

Ključne besede: zgodovina, kaznovanje, vzgoja, utilitaristične politike, retributivistične politike, abolicionizem, pravičnost v izobraževanju, ničta toleranca, inkluzija

\section{UINDERSTANDING OF THE PAST AND PRESENT MEANING OF PUINISHMENT AND PENAL POLICIES - ABSTRACT}

Punishment has a dual meaning: it is necessary because it leads to a change in behavior, but it also causes emotional imbalance between teachers and pupils. There are three basic theories of punishment - retributivism, which requires punishment as a method that will stop the individual from wanting to repeat the offense; utilitarianism, in which the primary goal of punishment is changing the individual, whereas the abolitionism theory searches for alternative forms of resolving disputes and deviant behavior. Zero tolerance means application of the same penalties for minor and major transgressions. Its opposite is inclusion, aimed at enabling people of different abilities to live together in peace and develop positive values. It is hard to imagine upbringing without punishment, despite the fact that the use of sanctions have negative effects. Theoretically speaking, if punishment is whatever an individual experiences as unpleasantness, then penalty cannot be eliminated in upbringing. Classic penalties can be replaced by measures proposed by opponents of traditional punishment.

Keywords: punishment, retributivism, utilitarianism, abolitionism theory, zero tolerance, inclusion

UDK: 37.091 .5

\section{RAZUMEVANJE KAZNOVANIA NEKOČ}

Razumevanje koncepta kaznovanja se je skozi zgodovino človeštva nenehno spreminjalo. $\mathrm{V}$ srednjeveški sholastični pedagogiki je prevladovala miselnost, da se posameznik rodi slab in da je zato primerna le kruta vzgoja $s$ kaznovanjem v smislu: »kdor ne rabi palice, mrzi svojega otroka, kogar ne vzgaja šiba, ni vzgojen ipd.« (Strmčnik, 2003: 275). Ni upoštevala individualnosti in je upravičevala ka- znovanje nekoga, ki še ni zrel za prevzemanje odgovornosti za lastna dejanja. Od renesanse naprej vprašanje uporabe kazni v pedagoške namene spremlja nekakšno nelagodje. Na eni strani se zdi, da je uporaba kazni v nekaterih primerih nujno zlo, če želimo posameznika, ki se ne odziva zgolj na spodbude, preusmeriti $\mathrm{k}$ primernim oblikam obnašanja. Na drugi strani pa uporabo kazni ponavadi spremlja negati- 
ven učinek - porušenje pozitivnega čustvenega stika med otrokom in vzgojiteljem, brez katerega ni mogoče pričakovati nadaljnjih vzgojnih učinkov (Kroflič, 2003: 375). Kazen v pedagoškem procesu je včasih nujna, hkrati pa nezaželena. Da je kazen v pedagoškem procesu nujna, potrjuje tudi Z. Kodelja (Kodelja, 2006: 233), ki piše, da je potrebna tako za otrokov moralni razvoj kakor tudi za razvoj njegovega pojmovanja pravičnosti. Brez kazni nista mogoča niti razvoj moralnega presojanja niti moralno ravnanje (prav tam: 240)

Kljub miselnosti srednjeveške sholastične pedagogike, da je kaznovanje nujno, v nadaljevanju analiziramo, ali lahko govorimo o vzgoji brez kaznovanja. Rousseau je utemeljil koncept naravne vzgoje, ki pravi, da otrok ne potrebuje discipline, saj mejo, ki jo prestopa, spozna tako, da občuti posledico odpora narave. Kaznovanje je odveč, saj kazen čuti kot naravno posledico storjenega dejanja. Edino sredstvo naravne vzgoje je »dobro urejena svoboda« (Kroflič, 1997: 222). Vendar je »dobro urejena svoboda « le navidezna svoboda, ki se izkaže za spretno manipulacijo, ki se ji otrok ne more upirati. R. Kroflič meni, da popolnoma svobodna vzgoja ni primerna, saj otrok potrebuje omejitve: »Ker tako na kazen kot na problem discipliniranja in omejevanja otroka gledam najprej s perspektive otrokovega doživljanja, zagovarjam trditev, da se v vzgoji za oblikovanje samostojne, kritične, odgovorne in etično občutljive osebnosti tem neprijetnim vzgojnim ukrepom ne moremo izogniti niti jim ne smemo vnaprej odreči možnost pozitivnih pedagoških učinkov.« (Kroflič, 2003: 374.) Rousseau je skušal vzgajati brez nasilja in kaznovanja, vendar se kazni ni mogel izogniti, saj naravna vzgoja vključuje naravno kazen. Pravzaprav je le malo avtorjev v zgodovini pedagogike, ki so se kaznovanju odrekli.

Pomembnosti kaznovanja se je zavedal tudi J. A. Komensky, ki je trdil, da šola brez discipline ne more obstajati. Kaznovanje je uporabljal zaradi moralnega razvoja in ne zaradi učenja:
»Strožja disciplina pa se ne sme uporabljati za to, da bi učenci v študiju napredovali, marveč da bi moralno uspevali.« (Komensky, 1958: 143.) Telesno kazen in silo je odsvetoval, uporabljal pa jo je pri verski vzgoji (prav tam: 144). Komensky se je zavedal negativnega vpliva kaznovanja, hkrati pa je vedel, da brez njega ne gre. Ni zanikal, da je kazen v vzgoji pomemben del: »Na Češkem vobče znani ljudski pregovor 'Šola brez discipline je kot mlin brez vode' je popolnoma resničen. «(Prav tam: 143.)

Nekoliko drugačnega mnenja pa so bili njegovi nasledniki. J. Locke je menil, da stroge kazni naredijo malo dobrega, blažje kazni pa je dopuščal in tudi uporabljal. V svojem delu je napisal, da telesnih kazni načeloma ne odobrava, saj je bil prepričan, da te otroka ne poboljšajo. Otroka lahko telesno kaznujemo in bo ubogal, a ko ga ne bomo nadzirali, bo počel ravno tisto, zaradi česar je bil kaznovan. Telesno kazen pa je kljub veliko negativnim posledicam $\mathrm{v}$ skrajnih primerih odobril, predvsem takrat, ko nobeno drugo sredstvo ni učinkovalo. Sicer se je zavzemal za kazni v obliki socialnega ignoriranja in za odvzem prostosti za določen čas (Locke, 2007: 40-47). Zadevo si je zamislil celo tako, da naj v nujnem primeru telesno kazen predpiše učitelj, izvrši pa naj jo domači služabnik, saj bo s tem otrok kaznovan, starš pa bo ohranil avtoriteto (prav tam: 72). John Locke je bil torej proti strogi telesni kazni, a jo je odobraval, če nobeno drugo vzgojno sredstvo ni učinkovalo. Avtorji so zavračali strogost v vzgoji in jo dopuščali le v skrajnih primerih, kar lahko pomeni, da so nekoč verjeli v vzgojno moč drugih strategij discipliniranja in ne samo strogega kaznovanja.

V 19. stoletju so se v našem šolstvu zgodile mnoge spremembe, ki so se nanašale na kaznovanje. Šolski in učni red je 20. avgusta 1870 prepovedal telesno kazen v šolah: »Telesno pokorilo v šolo nikjer in nikdar ne sme priti.« (J. R-lj., S. Punčah, 1877: 287.) Učitelji so ob tem zakonu Franca Jožefa negodovali, češ da jim je bilo odvzeto najučinkovitejše vzgojno 
sredstvo (Kroflič, 2003: 376). Kljub zakonski prepovedi se je telesna kazen še vedno uporabljala, a le kot skrajno vzgojno sredstvo, o katerem priča tudi ta zapis o razmišljanju ob uvedbi zakona: »Telesno pokorilo naj bode dovoljeno, pa le pogojno, v slučajih skrajne sile.« (J. R-lj., S. Punčah, 1877: 287.) V 19. stoletju na razvoj pedagogike pomembno vpliva Don Bosco, ustanovitelj Oratorija svetega Frančiška Saleškega (Kodelja, 1995: 26). Njegovo načelo pri kaznovanju je bilo preprečiti ponovitev prestopka (prav tam: 66). Kaznovanje pa je imelo pri Don Boscu drugoten pomen. Izhodišče je bilo, da se gojenec ne kaznuje; če preventiva ne deluje, pa je treba upoštevati nekatere napotke. Vzgojitelj mora poskrbeti, da ga bodo gojenci ljubili, če hoče, da bodo njegove vzgojne metode učinkovite. Za gojenca je kazen tisto, kar kot kazen uporablja učitelj. Graja se mora vedno izreči zasebno. Telesne kazni pa so povsem prepovedane (prav tam: 94-95). Don Bosco pa kazni vendarle ni popolnoma izključil iz sistema vzgoje svojih gojencev. Uporabljal je grožnjo Z večno kaznijo - božjo pokoro (prav tam). S to grožnjo na mesto avtoritete ni postavil sebe, ampak višjo silo, ki ji je moral odgovarjati tudi Don Bosco sam. S tem je dosegel, da so se gojenci vedli primerno tudi takrat, ko vzgojitelja ni bilo poleg, saj jih je nadzorovala višja sila - bog, ki vse vidi.

V pedagogiki 20. stoletja so bile kazni zmerne in $\mathrm{v}$ sorazmerju s prestopki ter so imele namen obrambe družbe pred kršitelji (Foucault, 2004: 102). Niso se smele uporabljati glede na »zločin«, ampak glede na možnost, da bi se prestopek ponovil. Ukrepati je treba tako, da tisti, ki je napako storil, ne bo želel, da bi znova kaj zagrešil, ter da ne bi mogel imeti posnemovalcev (Barnave v Foucault, 2004: 105). C. Beccaria (Beccaria, 2002: 36) je pisal, da je namen kazni preprečiti krivcu delati škodo svojim sodržavljanom in druge odvračati od podobnih dejanj. Ena izmed glavnih funkcij kaznovanja 20. stoletja je bila preprečevanje povzročanja škode sodržavljanom in preprečevanje ponavljanja prestopkov.

Razumevanje kaznovanja v sodobnejšem času opiše Z. Kanduč, ki pravi, da klasična kriminologija ${ }^{1}$ kazen opredeljuje kot »zlo«, ki pa je upravičeno, če je za družbo koristno. Namen kaznovanja je preprečevati ponovitev dejanj, vse druge možne kršilce je treba zastrašiti, da ne bodo sledili prestopnikovemu zgledu ali podlegli podobni skušnjavi: »Kazen in način njene izvršitve je zatorej treba izbrati tako, da se doseže najučinkovitejši in trajen vtis $v$ duševnosti ljudi, hkrati pa se telesu hudodelca zada kar najmanj muk. « (Beccaria v Kanduč, 1999: 49.)

Zgodovina pedagogike priča, da se različni misleci, filozofi in pedagogi kaznovanju niso popolnoma odrekli, temveč so ga dopuščali v skrajnih primerih, kar lahko razumemo, da so verjeli tudi v druge oblike discipliniranja otrok in ne le strogo kaznovanje. Če je kazen edina stvar, ki jo »kaznovani« doživlja kot neprijetnost, potem se teoretično temu v vzgoji ni možno izogniti, lahko pa kazen nadomestimo z drugimi ukrepi, kot jih npr. predlagajo zagovorniki abolicionistične in drugih teorij kaznovanja, kar bomo spoznali v nadaljevanju.

\section{TEORIJE KAZNOVANJA}

Kaznovanje naj bi učinkovalo tako, da posameznik po izvršeni kazni ne bi imel več želje po ponovitvi prestopka. Z. Kanduč (Kanduč, 1999: 49-50) razlaga, da ima kaznovanje dva naslovnika: dejanskega kršilca in skupino možnih ali potencialnih kršilcev. M. Foucault (Foucault, 2004: 94-96) takšen način kaznovanja imenuje »pravilo stranskih učinkov«. Zločinca naj bi kaznovali z najmanjšo možno 
kaznijo, medtem ko bi gledalci (potencialni prestopniki) to kazen doživeli kot eno hujših in s tem začutili odpor do ponovitve zločina (prav tam). Kaznovanje mora na posameznika učinkovati tako, da v mislih naredi povezavo med predstavo zločina in predstavo kazni. Tako se mu mora vsakič, ko pomisli na zločin (ali si ga zaželi), v zavesti takoj prikazati podoba kazenske sankcije, ki posameznika odvrne od zločina (Kanduč, 1999: 50). Seveda pa morajo biti pri tem izpolnjeni nekateri pogoji. Foucault (v Kanduč, prav tam) navaja, da mora biti kazen, če želimo, da bo delovala, javna, hkrati pa mora imeti jasno sporočilo o neponovitvi zločina ter mora zajeti širok spekter družbenega prostora. Kot drugi pogoj zapiše, da mora kazen simbolično predstavljati vsebino prestopka. To pomeni, da se npr. denarni prekrški sankcionirajo z globami in drugimi denarnimi sankcijami. Tretji pogoj je, da mora biti kazen najbolj verjetna posledica zločina. Kazen, ki se izvrši, ima veliko večji učinek kot samo strah pred kaznijo. Četrti pogoj je, da mora kazen slediti takoj po narejenem zločinu. »Krajši je presledek med prestopkom in kaznijo, močnejša in trajnejša je v človekovi duševnosti povezava med idejo zločina in njegovo (nujno in neogibno) pravno posledico.« (Beccaria v Kanduč, 1999: 50.) Peti in zadnji pogoj je, da mora biti kazen sorazmerna teži prestopka, ta pa je odvisna od storilčeve namere, dostojanstva oškodovane stranke in religiozne nevrednosti prestopka (prav tam). Takšno zastraševanje in odvračanje od odklonskega vedenja je retributivistično orientirano. Mogoča pa je tudi prevzgoja posameznika, torej da mu ustvarimo notranjo željo po neponovitvi odklonskih dejanj.

V grobem lahko teorije kaznovanja razdelimo v dve skupini. D. Petrovec (Petrovec, 1998: 11) jih deli na absolutne (retributivistične), ki kaznujejo zato, ker je storilec grešil, in ga nikakor ne kaznujejo zato, da bi ga spreminjale, saj s kaznijo le vzpostavljajo porušeni red. Druge, relativne ali tudi utilitaristične teorije trdijo, da je treba človeka prilagajati družbenemu okolju in prevzgojno vplivati nanj (prav tam). D. Petrovec (prav tam: 52-53) je zagovornik utilitaristične kaznovalne teorije in poskuša celo dokazati, da so zagovorniki retributivne teorije kaznovanja $\mathrm{v}$ slepi ulici. Retributivizem odgovarja na vprašanje, kdaj lahko logično kaznujemo in $\mathrm{v}$ katerih posamičnih primerih lahko kazen uporabimo, utilitarizem pa, kdaj bi (moralno) morali kaznovati in katera dejanja so kazniva (prav tam). Tudi Z. Kanduč (Kanduč, 1999: 123) piše o teh dveh teorijah. Privrženci utilitaristične teorije poskušajo mogoče kršitve preprečiti in $s$ tem odvrniti potencialne kršilce. Retributivistične teorije kaznovanja pa temeljijo na preprečevanju, zastraševanju in odvračanju ter na posledicah kršitve. E. Durkheim (v Kanduč, prav tam) priznava, da strah pred kaznijo vpliva na vedenje nekaterih posameznikov, vendar pa v splošnem ne more spremeniti njihovega moralnega življenja. Zanj ima kazen moralno vrednost, če jo kaznovani prizna kot pravično (Durkheim, 2009: 30). Ne verjame pa, da kazen poboljšuje, ker ne more ustvariti nagnjenja k dobremu vedenju (Kanduč, 1999: 123). Durkheim ne zaupa $\mathrm{v}$ poboljševalno funkcijo kazni kot take, če deluje po načelu strahu pred ponovnim kaznovanjem, verjame pa v moralno vrednost kazni, če jo kaznovani prizna kot legitimno (če kaznovani prizna avtoriteto in se ji podredi). Moralna vrednost kazni se kaže v tem, da se v posamezniku vzpostavijo moralna občutja, ki posameznika odvračajo od ponovitve »nemoralnega « vedenja.

Iz severnoameriškega gibanja za odpravo zaporov in zaporne kazni se je rodila teorija kaznovanja, ki je izhajala iz religioznih prepričanj in protisuženjskega gibanja - abolicionizem. Z. Kanduč (1999: 264) piše o tem kompleksnem pojavu, ki ima tri glavne razsežnosti: (1) je družbeno gibanje, ki si dolgoročno prizadeva odpraviti zapore in celotni kazenskopravni sistem, na krajši rok pa se zavzema za nenehno izboljševanje položaja obsojencev, 
ki prestajajo »prostostno« kazen, (2) je teoretska perspektiva, ki obsega »negativno« kritiko kazenskega prava in »pozitivno « oblikovanje alternativ, (3) je politična strategija, ki je usmerjena $\mathrm{v}$ omejevanje kazenskega prava in iskanje boljših načinov za reševanje družbenih problemov in medosebnih sporov (prav tam). Ravno zadnja točka Kandučeve navedbe nam poda še eno teorijo kaznovanja, ki je med retributivistično in utilitaristično teorijo kaznovanja. Privrženci abolicionizma se zavzemajo za iskanje alternativnih oblik reševanja sporov, zmanjševanje vloge zaporov in zapornih kazni. Haan (v Kanduč, 1999: 274) predlaga sklop raznovrstnih ukrepov, ki jih označuje s skupnih imenom »redress « in pomenijo zbir konstruktivnih in reparativnih reakcij ${ }^{2}$ na problematično situacijo. ${ }^{3}$ Kljub zelo pozitivnim opredelitvam abolicionizma se slednje zdijo preveč optimistične. Očitkov na račun abolicionističnih zamisli ne manjka. Kritiki zatrjujejo, da so abolicionistični predlogi naivni, idealistični, nostalgični, predvsem pa nezdružljivi z naravo postmoderne družbe (prav tam: 276). Pomemben pogoj za uvedbo alternativnih načinov reševanja sporov in odzivanj na škodljive dogodke bi bil, da se ljudje sami naučijo reševati probleme, ki se nenehno pojavljajo v družbeni skupnosti in medosebnih odnosih (prav tam: 277).

Vsaka teorija ima svojo zasnovo in svoje privržence. Absolutne teorije kaznovanja so zasnovane na načelu retribucije ali povračila za storjeno dejanje in se ne ozirajo na posameznika, njegove potrebe in na to, zakaj je do odklonskega vedenja prišlo. Utilitaristične teorije želijo posameznika spremeniti in ga prilagoditi njegovemu okolju. Abolicionistične usmeritve pa zločina sploh ne priznavajo in se zavzemajo za odpravo kaznovanja. Abolicionisti dokazujejo, da kazenskega prava (oziroma kaznovanja) ni mogoče upravičiti. ${ }^{4}$ Zamisel o pravični ali zasluženi kazni je zanje absurdna. ${ }^{5}$ Zanje rešitev ni v kopičenju bolečin, ampak v izogibanju zadajanja bolečin (Kanduč, 1999: 269).
Pomembno pa je tudi abolicionistično dojemanje zločina, ki zanje kot posebna ontološka kategorija ne obstaja. ${ }^{6}$

I. Kant (v Salecl, 1991: 102) je nasprotnik vseh utilitarističnih idej kaznovanja, po katerih je namen kazni prevzgoja in zastraševanje oziroma moralni vpliv na druge. Moralna pravica kaznovanja izhaja le iz tega, da je nekdo naredil prestopek, kršil zakon, ne pa iz posledic, ki naj bi jih kazen prinesla zločincu ali družbi (prav tam). Čisto drugače pa meni o kaznovanju otrok. Pri kaznovanju otrok je treba vedno imeti neko misel, ki ima za cilj izboljšanje otroka in njegovega vedenja. Retributivizem se sprevrže v čisti utilitarizem. Otroku zunanja prisila in prisila zakona še nista ponotranjeni, zato šele pri odraslih lahko govorimo o pogojih za retributivno kaznovanje. Torej le pri odraslem lahko govorimo o moralni pravici kršilca, da je kaznovan (prav tam). Otroke je treba kaznovati drugače, $v$ mislih je treba imeti, da želimo otroke spremeniti. Tako retributivistični teoriji kaznovanja ne smemo $\mathrm{v}$ popolnosti odreči pozitivnih učinkov. M. Javornik meni, da zagovorniki retributivističnega pristopa ne pozabijo na storilca. Verjamejo, da ima lahko pravična kazen pozitivne učinke na storilca in tako lahko $\mathrm{v}$ njem zbudi pozitivne spremembe. Pojavi se zahteva, da je treba spremeniti osebnost storilca, ker je ta družbeno neustrezna, in sicer s prevzgojnim delom (Javornik, 2001: 30). M. Javornik pravi, da kazen lahko deluje vzgojno, vendar mora biti ob tem pravična. Da pa bi bila pravična, mora izpolnjevati dva pogoja, piše Z. Kodelja: biti mora zaslužena, strogost kazni pa mora biti sorazmerna teži storjenega delikta. $\mathrm{Z}$ vidika retributivne teorije je kazen pravična samo, če je zaslužena, obenem pa ni pretirana in nesorazmerna storjenemu deliktu. Nezaslužena pa je takrat, ko je naložena nedolžnemu človeku, če delikt ni resničen delikt in če je pretirana (Kodelja, 2006: 241). Tudi M. Javornik (Javornik, 2001: 28) piše, da je kazen pravična, če je enakovredna strojenemu nepravu, če je čim 
bolj vrednostno sorazmerna dejanju. Z. Kanduč (v Javornik, prav tam) pa še dodaja, da ni mogoče povsem precizno, enkrat za vselej in za vsako dejanje določiti kazni, ki bo ustrezna. Z. Pavlović (v Šelih, 1996: 65) o pravičnosti napiše, da ta niha med dvema konceptoma: med enakopravnostjo brez razlikovanja, ki omogoča enakovredne izobraževalne ponudbe za vsakogar, vsakemu kršitelju pravil pa enak odziv, utemeljen le na teži kršitve, in konceptom pravičnega upoštevanja empiričnih razlik. Da bi kazen lahko delovala vzgojno, mora biti najprej pravična. Z. Kodelja (Kodelja, 2006: 240) meni, da kazen ne more delovati vzgojno, če ravnanje ni v skladu $\mathrm{z}$ »etiko pravičnosti«, kot jo imenuje on.

\section{NIČTA TOLERANCA}

Ničta toleranca je politika reagiranja na odklonske pojave $\mathrm{v}$ šoli (in tudi širše) $\mathrm{v}$ Združenih državah Amerike, ki se je po mnenju večine uveljavila po sprejetju odloka o šolah brez orožja (Gun-Free School Act) leta 1994, izvori te politike pa segajo še v sedemdeseta leta prejšnjega stoletja (Kroflič, 2008). V tem obdobju je Nixonova politika napovedala vojno drogam, hkrati pa se je po krvavem uporu kaznjencev v Attici leta 1971 začela javnomnenjska in teoretska razprava o prevzgojni metodiki ukvarjanja s prestopniki, ki jo usmerja prepričanje, da je mogoče odklonsko vedenje zajeziti s kaznovanjem (prav tam). Začne se obdobje stroge kaznovalne politike, ki predvideva, da se posameznik strogo kaznuje po načelu, da je dovoljeno le omejeno število napak, potem sledi izključitev iz družbe (zapor) ne glede na težo storjenih prekrškov. Namen je pokazati drugim, da se »zločin « ne splača in naj zato takšnemu vedenju ne sledijo. Tudi R. J. Skiba (Skiba, 2000: 4) piše, da ničta toleranca predvideva enake kazni za manjše in večje prestopke, zato da bi bila kazen zgled preostalim. Včasih se zgodi, da se pri takšnem kaznovanju celo zgubi smisel za pravičnost, tako da so učenci kaznovani enako, če gre za resen prestopek (npr. nošenje orožja) ali le za neprimerno interpretacijo situacije (npr. učenka je kaznovana, ker je v šolo prinesla pilico za nohte) (prav tam: 5). R. J. Skiba opozarja, da takšen način kaznovanja lahko pripelje do resnejših posledic, kot je veliko večji delež enako kaznovanih za manjše prestopke kot tistih $\mathrm{z}$ večjimi prestopki (prav tam: 6). Z. Kodelja meni, da je uporaba strogih kazni za lažje delikte in milih za hude nepravična, ker kazen ni soraz-

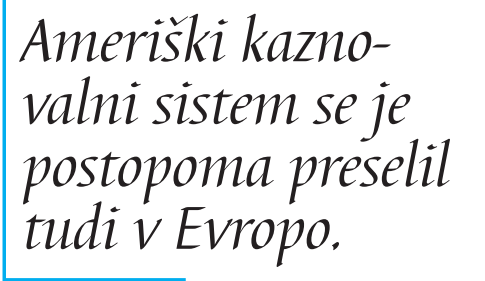
merna storjenemu deliktu. Ne glede na to pa je v okviru retributivne teorije pravične kazni jasno, da si samo tisti, ki so res krivi, zaslužijo kazen in da mora biti ta sorazmerna resnosti storjenih deliktov (Kodelja, 2006: 245-247). Kako uspešne so te šole, kaže podatek, da ne obstajajo konkretne raziskave, ki bi ugotavljale, ali so šole pri svojem početju uspešne ali ne (Skiba, 2000: 7). Nekatere šole sicer trdijo, da so pri uporabi ničte tolerance uspešne in da se je stopnja neprimernega vedenja $v$ šoli znižala, vendar tega ne moremo zagotovo trditi, saj o takšnih pričanjih nimamo konkretnih raziskav. O resnosti stanja ničte tolerance $v$ ZDA nam pričajo tudi različni podatki, kot npr. da se razširjenost resnih prekrškov v šolah dejansko ni zmanjšala in da je temeljni namen kaznovanja vzpostavitev avtoritete in ne sprememba posameznika ter da je prizadeto predvsem črnsko in hispanoameriško prebivalstvo (Kroflič, 2008). Tudi znani francoski filozof L. Wacquant (2002) piše o slabih razmerah na področju kaznovalnega sistema v ZDA, ki ga označuje kot inštrument za upravljanje in obstoj geta. V ZDA obstajajo štirje sistemi, ki skrbijo, da ostanejo Afroameričani v podrejenem položaju: suženjstvo, sistem Jima Crowa, urbani geto in vse bolj razširjeni zaporni sistem. Suženjstvo je poskrbelo, da so bili zadoščeni interesi po brezplačnem in izkoriščevalskem delu na plantažah. Sistem Jima Crowa se je pojavil po 
odpravi suženjstva v Ameriki in je omejeval ekonomske priložnosti Afroameričanov. Zanje so bila primerna nevarna in najbolj umazana dela $\mathrm{v}$ rudnikih in na bombažnih poljih, ki so bila »rezervirana« samo za črno populacijo. Omejevanje pa se je dogajalo tudi v vseh javnih ustanovah, barih, kinih, parkih, avtobusih, čakalnicah in javnih straniščih, kjer so bili Afroameričani diskriminirani. Zaradi krutosti sistema Jima Crowa (linčanja, preganjanja in diskriminacije) je ogromno Afroameričanov pobegnilo v severni del ZDA. Nastala so geta v večjih mestih, kot so Chicago, Detroit, New York in Philadelphia (prav tam).

Politika ničte tolerance izhaja še iz časa suŽenjstva in tudi iz kasnejših razmer v ZDA, ko se je nebelsko prebivalstvo zaprlo v geto. Geta so sčasoma postajala vse bolj kot zapori in zapori vse bolj kot geta. Politika ničte tolerance najbolj prizadene ranljive dele prebivalstva. $R$. J. Skiba navaja podatke, ki kažejo, da je bilo povprečje suspendiranih afroameriških dijakov dvakrat ali celo trikrat večje kot povprečje suspendiranih belih dijakov. Prav tako so afroameriški dijaki bolj izpostavljeni telesnemu kaznovanju in dobijo hujše kazni za manjše prestopke kot beli dijaki (Skiba, 2000: 11-12). Ameriški kaznovalni sistem se je postopoma preselil tudi v Evropo, predvsem v času, ko je dobil največ kritik. Zaznamujejo ga naslednje značilnosti: (1) vertikalna ekspanzija zaporov - populacija zaporov je skokovito narasla; (2) horizontalna ekspanzija kaznovalne mreže kaznovanje ni omejeno le na zapore, ampak vključuje tudi pogojne kazni, poskusne pogojne kazni in različne »tabore«; (3) »velika politika« kaznovanja - kaznovalni sistem se je razvil v multikapitalske industrije; (4) rast zasebnih kaznovalnih trgov - rast zasebnih zaporov in (5) etnične manjšine so bolj izpostavljene kaznovanju kot drugi. Wacquant ugotavlja, da zapor nadzoruje kriminaliteto z zapiranjem revnih in brezposelnih ter povečuje obseg etničnih manjšin. ZDA so šle v smeri kriminalizacije revščine, medtem ko je
Evropa še na začetku tega procesa (Wacquant v Deflem, 2010). Čeprav ima Evropa drugačno zgodovino in tradicijo kaznovanja, se ameriški sistem kaznovanja postopoma uveljavlja tudi pri nas. Vse bolj polni zapori po Evropi kažejo, da smo se približali ameriškemu standardu, kljub kritikam tega kaznovalnega sistema. L. Wacquant razlaga, da je to zato, ker morajo države utrjevati svojo moralno oblast v času ekonomske krize, to pa lahko storijo predvsem z zapiranjem posameznikov, ki so $\mathrm{v}$ družbi nekoristni in nezaželeni. Zasebni zapori poleg tega prinašajo tudi dobiček. Kot kaže, se je število zasebnih zaporov v Veliki Britaniji z 200, kolikor jih je bilo leta 1993, do danes povzpelo na štiri tisoč. Drugi razlog za širjenje ameriškega kaznovalnega sistema pa so raziskave, ki jih pripravljajo raziskovalci, podrejeni političnemu vrhu, v katerih vladajoči skrivajo odločitve, ponavadi povezane $\mathrm{z}$ volitvami. Različni raziskovalci proizvajajo ravno takšne raziskave, ki so potem $\mathrm{v}$ prid vladajočim. Ljudje pa takšnim raziskavam verjamejo in se družbenemu ustroju tudi podredijo (Wacquant, 2008: 46-47).

Eden od pristopov, vzporeden teoriji ničte tolerance, ki ubira alternativen način $\mathrm{v}$ odzivanju na drugačnost $\mathrm{v}$ šolskem okolju, je inkluzija. Inkluzija je pojav, ki se ujema $\mathrm{z}$ današnjimi družbenimi gibanji pod imenoma multikulturnost in interkulturnost, in jo je zato treba gledati z dveh nivojev. Prvi je vključevanje tistih, ki jih danes sistem ali šola izključujeta. Torej inkluzija ne zadeva samo učencev s posebnimi potrebami, ampak tudi učence/otroke, ki jih je šola izključila zaradi neuspehov, učence/otroke, ki jih je izključilo socialno okolje, in učence/otroke, ki so se zaradi različnih razlogov sami potisnili na socialni rob (osebne nesreče, napačna odločitev pri izbiri šole, poklica itd.). Drugi nivo je prizadevanje, da bi v okviru šolskega okolja vsakemu otroku/učencu zagotovili izobrazbo, skladno z njegovimi potrebami, sposobnostmi, značilnostmi, zmožnostmi, ambicijami, posebnostmi (Resman, 2003: 64-66). 
Skozi zgodovino so se oblikovali različni pristopi k reševanju vprašanj drugačnosti. V prvi vrsti so prevladovali koncepti ločenosti (ločitev otrok/učencev na različne oddelke, na več različnih šol itd.), danes imamo možnost videti tudi druge pristope k obravnavanju izključenih otrok/učencev (Lesar, 2009). Na splošno so se oblikovale tri smeri: a) psiho-medicinska paradigma, ki je osredotočena na individualno raven; učne težave pojasnjuje s primanjkljaji posameznega učenca (Skidmore v Lesar, 2009: 73); b) sociološka paradigma daje poudarek družbeni ravni in postavlja v ospredje sistem reprodukcije strukturalnih neenakopravnosti z makro socialne ravni na institucionalno (Clark v prav tam); c) organizacijska paradigma je osredotočena na institucionalno raven; v njenem okviru naj bi učne težave izhajale iz primanjkljajev znotraj splošne organizacije šole (Skidmore $v$ prav tam).

Ravno zaradi svoje orientiranosti je inkluzija na svoj način nasprotje teorije ničte tolerance. James in Freeze (v Kroflič, 2008) proučujeta neinkluzivnost politike ničte tolerance in s tem ugotavljata razlike med tema dvema pristopoma. Dosedanja dejstva o pedagoških orodjih in ugotovljeni učinki politike ničte tolerance govorijo o tem, da so tarče drastičnih ukrepov politike ničte tolerance učenci in dijaki iz najbolj ogroženih socialnih skupin. Z inkluzivnimi pristopi pa jih poskušajo obdržati v šolskem okolju in jim zagotoviti uspešno vključitev v družbo. Avtorja poskušata razlike med tema dvema pristopoma analizirati in jih postaviti v sistem kriterijev. Prvi kriterij je naraščanje števila problemov namesto njihovega reševanja, kar pomeni, da ničta toleranca probleme le premešča in jih dejansko ne odpravlja. Inkluzivne prakse pa poskušajo zagotoviti šolsko okolje, ki bo ogroženim posameznikom dalo občutek varnosti in sprejetosti ter razvijalo sprejemljivejše oblike vedenja (prav tam). Drugi kriterij je, da politika ničte tolarance ponuja enake sankcije za enake prekrške različne »težine«, medtem ko inkluzivna politika šteje takšen pristop za popolnoma nesprejemljiv. Tretji kriterij pa je, da si politika ničte tolerance ne prizadeva, da bi kaznovani posamezniki razumeli vzroke svojih dejanj in jih poskušali spremeniti, medtem ko inkluzivna praksa dela ravno to (prav tam). Ničta toleranca temelji na retribuciji, kar pomeni, da je posameznik enako kaznovan za svoje dejanje ali vedenje ne glede na težo svojega prekrška. V politiki ničte tolerance le malokdaj zasledimo drobce utilitarističnih usmeritev. R. Kroflič pravi (Kroflič, 2008), da ima ničta toleranca podpornike, ki menijo, da je lahko v praksi uspešna, če se uporablja z ustreznimi dopolnitvami. R. J. Skiba pa veliko piše o šolah, ki niso pripravljene prenehati uporabljati metode ničte tolerance, kljub pritiskom javnosti in staršev. V teh šolah menijo, da bi pogajanja povzročila vtis o neresnosti šole pri reševanju disciplinskih težav (Skiba, 2000: 7). Seveda pa tudi inkluzija rešitve ne zagotavlja samoumevno, ampak je uspeh inkluzivnega šolanja odvisen od vsakodnevnega dogajanja $\mathrm{v}$ razredih ter predpostavlja spreminjanje programa in načinov poučevanja za vse učence $v$ razredu. Inkluzivno šolanje zahteva sodelovanje učiteljev, staršev, terapevtov, specialnih pedagogov in vseh vključenih v posamezen obravnavani primer (Lesar, 2009: 75). Niti za izključevanje niti za inkluzijo ne moremo dokončno reči, da je bolj sprejemljivo. Poglobiti se je treba v vsak primer in znotraj tega priti do racionalne odločitve: »Kriterij 'resnice' mora biti otrok.« (Resman, 2003: 82.)

\section{ZAKLJUČEK}

V zgodovini kaznovanja ugotavljamo, da se nihče, ki se je ukvarjal z vzgojo, ni v popolnosti odrekel kazni. Ravno nasprotno, pri vzgoji so jo uporabljali in priporočali, vendar vedno zmerno in premišljeno ali pa le v skrajnih primerih. Kazen ima pri vzgoji otrok dvojni uči- 
nek. Na eni strani je nujna, saj privede do spoznanja o zmotnem ravnanju in s tem odvrača od ponovitve deviantnih dejanj. Na drugi strani pa povzroča čustveno neravnovesje med učiteljem in gojencem, kar onemogoča nadaljnje sodelovanje med njima. Kljub negativni strani kazni pa je ta včasih nujna. Poraja se vprašanje, kakšna naj bo. Pri odgovarjanju na to vprašanje imamo na voljo tri temeljne teorije kaznovanja. Retributivistično usmerjeni avtorji zagovarjajo vzgojno funkcijo kazni. Ta na posameznika deluje tako, da dejanja ne bo želel ponoviti. Verjamejo, da lahko pravična kazen v posamezniku vzbudi spremembo, ki je pozitivno naravnana, zato pri otrocih lahko govorimo o pogojih za retributivno kaznovanje. Za utilitariste je temeljni cilj kaznovanja sprememba posameznika. Posameznik si dejanja ne želi več ponoviti, ker smo nanj vplivali tako, da se je v njem zgodila sprememba njegovih stališč in vrednot. To pomeni, da če nekomu koristimo tako, da ga ne kaznujemo, potem ga raje ne kaznujmo. Sprejemljivo je namreč vse, kar lahko posameznika pripelje do spremembe. Za odgovor na vprašanje, kakšna naj bo kazen, bi morali izoblikovati neka splošna načela, kot je to za discipliniranje storila M. Pšunder (2006). Tretja teorija kaznovanja je abolicionizem, ki se uvršča med retributivistično in utilitaristično teorijo kaznovanja in zločina kot takega ne priznava. Abolicionisti se zavzemajo za alternativne oblike reševanja sporov in deviantnega vedenja. Kaznovalne metode je treba nadomestiti z bolj »civiliziranimi« mehanizmi, kot so sprava, pomiritev, odprava škode, pogajanje, posredovanje v sporu, civilnopravne in upravnopravne sankcije. Ali so takšne metode uspešne $\mathrm{v}$ vzgojnem procesu in ali se ob tem razvija moralna zavest? Abolicionisti menijo, da je kaznovanje v najboljšem primeru nekoristno, v najslabšem pa škodljivo in kontraproduktivno (Kanduč, 1999: 263). Torej kaznovanje (v popolnosti) zavračajo.

Pri analiziranju učinkov ničte tolerance smo ugotovili, da predvideva enake kazni za večje in manjše prestopke. Posledice pa so, da se število prekrškov, kljub temu da so strogo kaznovani, ni zmanjšalo. Vzpostavlja se vse večja avtoriteta šol, ki se bojijo izgubiti kredibilnost, zato kazni ne zmanjšujejo in ne omilijo. $\mathrm{Ob}$ tem so prizadeti najbolj ranljivi deli populacije, predvsem Afroameričani in Hispanoameričani. Kljub mnogim kritikam ničte tolerance se ta uveljavlja tudi drugod po svetu, celo v Evropi. Razlogi za to so želja po večji dobičkonosnosti, ki jo prinaša odpiranje vse več zasebnih zaporov. Drugi razlog je povezan z volitvami. Politiki poskušajo proizvajati takšne raziskave, ki jim bodo pomagale pri izvolitvi. Čeprav je na račun ničte tolerance veliko kritik, ima ta še vedno ogromno podpornikov. Sami se z njo ne strinjamo in menimo, da čeprav je kaznovanje $\mathrm{v}$ vzgojnem procesu in tudi kasneje v življenju potrebno, mora vendarle biti v skladu s prekrškom in imeti za rezultat spremembo vedenja in neponovitev deviantnega dejanja.

Spoznali smo tudi drug pristop k obravnavanju drugačnosti $v$ šolskem okolju, to je inkluzija, ki ima za cilj strpno življenje različnih socialnih, kulturnih, verskih, političnih in drugih skupin. Prizadeva si za mirno sožitje ljudi različnih sposobnosti ter socialnih in kulturnih korenin ter za razvijanje vrednot, kot so razumevanje, toleranca, spoštovanje drugega in drugačnosti (Resman, 2003). Za noben pristop pa ne moremo trditi, da je ekskluziven, saj se je treba ob posameznih primerih odločiti situaciji primerno, kjer je kriterij otrok in ne zavzemanje za določen položaj za vsako ceno. Vrnimo se h glavni temi prispevka, in sicer, ali je kaznovanje v vzgoji potrebno ter ali obstajajo alternativne oblike prevzgoje posameznika, ki bi jih uporabljali namesto kaznovanja. Skozi preučevanje mnenj različnih avtorjev smo ugotovili, da popolnoma brez kazni ne gre. Čeprav uporabo kazni ponavadi spremlja negativen učinek, pa kazen prinaša tudi spremembo vedenja, kar je velikokrat tudi cilj vzgoje. Uporabimo lahko različne pristope $\mathrm{k}$ prevzgoji otrok, vendar moramo pri tem pazi- 
ti, da vedno izhajamo iz otroka in ugotovimo, kaj pri posameznem otroku in $\mathrm{v}$ dani situaciji deluje. Teoretično gledano, če je kazen vse, kar kaznovani doživlja kot neprijetno, potem kazni v vzgoji ni mogoče odpraviti. Klasične kazni pa je mogoče nadomestiti z ukrepi, ki jih predlagajo nasprotniki klasičnega kaznovanja, npr. poravnava škode, mediacija itd.

\section{LITERATURA}

Beccaria, C. (2002). O zločinih in kaznih. Ljubljana: Cankarjeva založba.

Deflem, M. (2010). Book Review. Punishment and Society. Thousand Oaks, CA and New Delhi. SAGE Publications, London. Pridobljeno dne 15. 8. $2010 \mathrm{~s}$ svetovnega spleta: http://www.cas. sc.edu/socy/faculty/deflem/zwacqrew.pdf.

Durkheim. E. (2009). Vzgoja in sociologija. Ljubljana: Krtina.

Foucault, M. (2004). Nadzorovanje in kaznovanje, Nastanek zapora. Ljubljana: Krtina.

J. R-lj., S. Punčah. (1877). »Dopisi in novice«. Učiteljski tovariš, 18: 285-288.

Javornik, M. (2001). O problematiki vzgoje v kazenskem pravu. Doktorska disertacija. Ljubljana: Filozofska fakulteta Univerze v Ljubljani.

Kanduč, Z. (1999). Kriminologija: (stran)poti vede o (stran)poteh. Ljubljana: Inštitut za kriminologijo na Pravni fakulteti.

Kodelja, Z. (1995). Objekt vzgoje. Ljubljana: Krtina.

Kodelja, Z. (2006). O pravičnosti v izobraževanju. Ljubljana: Založba Krtina.

Komensky, J. A. (1958). Velika didaktika. Ljubljana: Zveza pedagoških društev LR.

Kroflič, R. (1997). Avtoriteta v vzgoji. Ljubljana: Znanstveno in publicistično središče.

Kroflič, R. (2003). »O pedagoški vrednosti kazni«. Šolska kronika, 2: 374-384.

Kroflič, R. (2008). »Ničta toleranca do odklonskega vedenja in inkluzivna šola«. Sodobna pedagogika, 3: 64-74.

Kroflič, R. (2010). Se je v vzgoji mogoče izogniti kaznovanju. Delovna verzija. Pridobljeno s svetovnega spleta dne 15. 8. 2010: www2.arnes.si/ rkrofl1/ Teksti/kazen\%20v\%20vzgoji.doc.

Lesar, I. (2009). »Kaj ideja inkluzije predpostavlja od šol in učiteljev? «V: Nives L. (ur.): Pedagoško-andragoški dnevi 2009. Misliti vzgojo: problemi oblikovanja vzgojno-izobraževalnega koncepta. Zbornik. Ljubljana.
Locke, J. (2007). Nekaj misli o vzgoji. Ljubljana: Pedagoška fakulteta.

Pavlović, Z. (1990). Psihološke pravice otrok. Ljubljana: Društvo psihologov Slovenije.

Pavlović, Z. (1996). »Vzgojni in disciplinski ukrepi kot način obravnavanja motenj učnega procesa in kot vzgoja otrok za sprejemanje lastne odgovornosti«. V: Šelih, A., Otrokove pravice, šolska pravila in nasilje $v$ šoli. Ljubljana.

Petrovec, D. (1998). Kazen brez zločina: prispevek k ideologijam kaznovanja. Ljubljana: Studia humanitatis.

Pšunder, M. (2006). »Načela disciplinskega pristopa (Izhodišča in stališča nekaterih avtorjev)«. Sodobna pedagogika, 1: 130-145.

Resman, M. (2003). »Integracija/inkluzija med zamislijo in uresničevanjem«. Sodobna pedagogika, posebna izdaja: 64-83.

Rousseau, J. J. (1997). Emil ali o vzgoji. Novo mesto: Pedagoška obzorja.

Salecl, R. (1991). Disciplina kot pogoj svobode. Ljubljana: Krt.

Skiba, R. J. (2000). Zero Tolerance, Zero Evidence. An Analysis of School Disciplinary Practice. Indiana Education Policy Center. Pridobljeno dne 21. 8. 2010 s svetovnega spleta: http://www. indiana.edu/ safesch/publication.html.

Strmčnik, F. (2003). »Zgodovinski oris razumevanja in pomena pedagoške kazni«. Šolska kronika, 2: 274-296.

Strmčnik, F. (1968). »Jana A. Komenskega nazori o šolski kazni«. Sodobna pedagogika, 1-2: 1-4.

Wacquant, L. (2002). Deadly Symbiosis, Rethinking race and imprisonment in twenty-first-century America. Boston Review. Pridobljeno dne 15. 8. 2010 s svetovnega spleta: http://bostonreview.net/ BR27.2/wacquant.html.

Wacquant, L. (2008). Zapori revščine. Ljubljana: Založba /*cf., Rdeča zbirka.

$1 V$ nasprotju z retributivističnimi ali absolutističnimi pojmovanji kazni, ki utemeljujejo kaznovanje kot nekaj notranje dobrega, dasi subjektiono bolečega (Kanduč, 1999: 49).

2 V nadaljevanju jo poimenuje reparacija.

3 Njena vsebina je opredeljena v vsakem konkretnem primeru posebej in ni določena vnaprej. Vse je mogoče, če je sporazumno sprejeto kot rešitev za "problematično situacijo«. Če nekdo zahteva reparacijo, to pomeni, da je treba začeti razumno razpravo, ki pokaže: (1) kaj se je 
dejansko zgodilo in (2) kako bi najbolje razrešili nastali spor (Kanduč, 1999: 274).

4 Ni ga mogoče upravičiti ne normationo ne pravnofilozofsko (Kanduč, 1999: 269).

5 Haan (v Kanduč, 1999: 269) pravi, da je smešno trditi, da je mogoče eno bolečino kompenzirati ali izničiti $z$ drugo.

6 Abolicionisti niso edini, ki ne priznavajo ontološke realnosti zločina. Že teorija etiketiranja (labeling approach), ki je nastala $v$ štiridesetih letih prejšnjega stoletja, je zavrnila ustaljene predstave o kriminalu in deviacijah. Kriminalnost je zoolj etiketa, ki se predpiše v procesih odzivanja na nekatera dejanja (Kanduč, 1999: 271). 